\title{
Pengaturan dan Implementasi Prinsip Netralitas Aparatur Sipil Negara di Indonesia
}

\author{
Bagus Sarnawa
}

DATA NASKAH

Masuk: 22 Maret 2017

Diterima: 1 Mei 2017

Terbit: 1 Juni 2017

KORESPONDEN PENULIS: Fakultas Hukum, Universitas Muhammadiyah Yogyakarta Jalan Lingkar Selatan, Tamantirto, Kasihan, Yogyakarta, 55183. Telp.0274-387656, Fax: 0274387646. Email:

bagussarnawa@umy.ac.id

\section{ABSTRACT}

The State Civil Apparatus has a very important role in the implementation of the tasks of government and nation-building. Therefore, the State Civil Apparatus is an apparatus free from political intervention. In other words, as stated in the legislation, the State Civil Apparatus must be neutral. The neutrality of the State Civil Apparatus is a prohibition for the State Civil Apparatus to become a member or manager of a political party, so that the Civil State Apparatus is free from the influence and intervention of political parties in the performance of their duties and obligations. The regulation of the neutrality of the new State Civil Apparatus began in the New Order period with the issuance of Law No. 8 of 1974, and so on in Law 43 of 1999 and Law No. 5 of 2014 on State Civil Apparatus and its implementing regulations. In practice, the implementation of neutrality of the State Civil Apparatus has many obstacles and constraints. At the time of enactment of Law No. 8 of 1974 and Law No. 43 of 1999, the principle of State Civil State's neutrality of neutrality is often violated, this is due to the strong influence of political parties in bureaucratic relations in government agencies. Therefore, in the period of Law No. 5 of 2014, efforts are made to minimize and even eliminate the influence of political parties on the State Civil Apparatus, one way is to establish the State Civil Apparatus Commission. Keywords: Neutrality, State Civil Apparatus, Intervention

\section{ABSTRAK}

Aparatur Sipil Negara (ASN) mempunyai peran sangat penting dalam pelaksanaan tugas-tugas pemerintahan dan pembangunan bangsa. Oleh sebab itu, ASN adalah aparatur yang bebas dari intervensi politik. Dengan kata lain, sebagaimana disebutkan dalam peraturan perundang-undangan, ASN harus netral. Netralitas ASN salah satunya adalah larangan menjadi anggota atau pengurus partai politik, sehingga terbebas dari pengaruh 
dan intervensi partai politik dalam pelaksanaan tugas dan kewajibannya. Pengaturan netralitas Aparatur Sipil Negara baru dimulai pada masa Orde Baru yaitu dengan diterbitkannya Undang-undang No.8 tahun 1974, seterusnya diatur dalam Undang Undang No.43 tahun 1999 dan Undang-undang No.5 tahun 2014 tentang Aparatur Sipil Negara beserta peraturan pelaksanaannya. Dalam prakteknya, implementasi netralitas Aparatur Sipil Negara mengalami banyak hambatan dan kendala. Pada saat berlakunya Undang-undang No.8 tahun 1974 dan Undang-undang No.43 tahun 1999, prinsip netralitas Aparatur Sipil Negara seringkali dilanggar, hal ini terjadi akibat kuatnya pengaruh partai politik dalam hubungan birokrasi di instansi pemerintahan. Oleh sebab itu, pada masa Undang Undang No.5 tahun 2014, dilakukan upaya untuk meminimalisasi bahkan menghapuskan pengaruh partai politik terhadap Aparatur Sipil Negara, salah satu caranya adalah dengan membentuk Komisi Aparatur Sipil Negara.

Kata kunci: Netralitas, Aparatur Sipil Negara, Intervensi

\section{PENDAHULUAN}

Aparatur Sipil Negara (ASN) adalah aktor penting dalam pelaksanaan pembangunan negara Indonesia. Hal ini dapat dilihat dalam alinea keempat Pembukaan Undang Undang Dasar 1945 (UUD 1945) yang menyebutkan "...kemudian daripada itu untuk membentuk suatu pemerintahan yang melindungi segenap bangsa Indonesia dan seluruh tanah tumpah darah Indonesia dan untuk memajukan kesejahteraan umum, mencerdaskan kehidupan bangsa, dan ikut melaksanakan ketertiban dunia yang berdasarkan perdamaian abadi dan keadilan sosial...". Alinea keempat Pembukaan UUD 1945 tersebut menimbulkan konsekuensi logis terhadap peran ASN dalam mewujudkan kesejahteraan rakyat. Kesejahteraan rakyat merupakan cita-cita dari negara kesejahteraan. Spicker (1988: 75) menyebutkan bahwa negara kesejahteraan adalah "a state which benefits its citizen in accordance with a certain set of principles from cradle to grave ".

Berdasar pendapat Spicker tersebut, ASN dalam negara kesejahteraan berperan sangat luas terhadap kehidupan masyarakat dalam upaya mewujudkan kesejahteraan dan kemakmuran, peran tersebut diwujudkan dengan campur tangan negara dalam kehidupan masyarakat (private). Undang undang No.5 tahun 2014 tentang Aparatur Sipil Negara menyebutkan bahwa:

"Dalam rangka mencapai tujuan nasional sebagaimana tercantum dalam alinea keempat Pembukaan Undang Undang Dasar 1945 diperlukan Aparatur Sipil Negara yang profesional, bebas dari intervensi politik, bersih dari praktik korupsi, kolusi dan nepotisme, mampu menjalankan pelayanan publik bagi masyarakat dan mampu menjalankan peran sebagai perekat persatuan dan kesatuan bangsa berdasarkan Pancasila dan Undang Undang Dasar 1945. Tujuan Nasional sebagaimana tercantum dalam alinea keempat Pembukaan Undang Undang Dasar 1945 adalah melindungi segenap bangsa Indonesia dan seluruh tanah tumpah darah Indonesia dan untuk memajukan kesejahteraan umum, mencerdaskan kehidupan bangsa, dan ikut melaksanakan ketertiban dunia yang berdasarkan perdamaian abadi dan keadilan sosial. Untuk mewujudkan tujuan nasional dibutuhkan pegawai Aparatur Sipil Negara"

Dengan demikian ASN bertugas melaksanakan fungsifungsi pemerintahan dan pembangunan serta fungsi pelayanan. Fungsi pemerintahan dilaksanakan dalam rangka penyelenggaraan fungsi umum pemerintahan yang meliputi pendayagunaan kelembagaan, kepegawaian, dan ketatalaksanaan. Sedangkan dalam rangka pelaksanaan fungsi pembangunan tertentu dilakukan melalui pembangunan bangsa (cultural and political development) serta melalui pembangunan ekonomi dan sosial (economic and social development) yang diarahkan meningkatkan kesejahteraan dan kemakmuran seluruh masyarakat. Fungsi pelayanan dilakukan dengan memberikan pelayanan atas barang, jasa, dan/atau pelayanan administratif yang disediakan Pegawai ASN (Sirajudin, et. al, 2011: 2).

Agung Kurniawan (2005: 3-4) menyebutkan tiga fungsi pemerintahan, yaitu: pertama, fungsi pengaturan yang dilaksanakan dengan membuat peraturan yang mengatur hubungan masyarakat; kedua, fungsi pemberdayaan yang diwujudkan dengan meningkatkan peran serta masyarakat 


\section{MEDIA
HUKUM}

dalam pembangunan dan pemerintahan; dan, ketiga fungsi pelayanan (verzorgen functie) yang diarahkan pada fungsi pemenuhan kebutuhan masyarakat sekaligus upaya penciptaan keadilan ditengah masyarakat.

Sejalan dengan hal tersebut di atas, Undang undang No.5 tahun 2014 tentang ASN, mengamanatkan untuk dilakukan pembinaan ASN. Effendi (2013:6) menyebutkan, pentingnya pembinaan ASN, karena disamping untuk melaksanaan fungsi-fungsi pemerintahan guna mencapai tujuan nasional juga untuk membentuk ASN yang berkemampuan dunia. Pembinaan ASN juga diarahkan bagi terwujudnya sikap netral dan bebas dari intervensi kekuasaan dan partai politik.

Dengan kata lain ketidaknetralan ASN dapat menimbulkan implikasi terhadap: (1) Diskriminasi dalam pelayanan birokrasi. Birokrasi berfungsi sebagai alat pengendali masyarakat dan alat mobilisasi masyarakat. (2) Terlalu banyak political appointment pada jabatan karier birokrasi dan munculnya birokrasi yang bersifat partisan. (3) Pengabaian prinsip meritokrasi dan berkembangnya praktek koneksi dan praktek rekrutmen, promosi dan demosi yang lebih didasarkan pada faktor askriptif, dan (4) Pelembagaan conflict of interest dan munculnya birokrasi berbisnis (Utomo, 2005: 6).

Dalam sejarah perjalanan negara Indonesia, pengaturan ASN tidak pernah terlepas dari kekuatan politik (penguasa yang berafiliasi pada partai politik), sejak zaman Orde Lama, Orde Baru, Orde Reformasi sampai sekarang. Peletakan hukum sebagai variabel yang bergantung atas politik atau politik yang determinan atas hukum itu mudah dipahami dengan melihat relitas, sekalipun pada dasarnya politik hukum mengarah pada pada perwujudan hukum/aturan yang baik, yaitu hukum yang memuat prinsip-prinsip keberlanjutan, berkeadilan, dan demokratis (Tanto Lailam, 2017: 158). Namun, pada pada kenyataannnya hukum dalam artian sebagai peraturan yang abstrak (pasal-pasal yang imperatif) merupakan kristalisasi dari kehendak politik yang saling berinteraksi dan bersaingan. Sidang parlemen bersama pemerintah untuk membuat undang undang sebagai produk hukum pada hakikatnya merupakan adegan kontestasi agar kepentingan dan aspirasi semua kekuatan politik dapat terakomodasi di dalam keputusan politik dan menjadi undang undang. Undang undang yang lahir dari kontestasi tersebut dengan mudah dapat dipandang sebagai produk dari adegan kontestasi politik itu. Inilah maksud pernyataan hukum merupakan produk politik (Mahfud, 1998:2)

Dengan demikian pengaturan dan implementasi netralitas ASN di negara kita mengalami dinamika pasang surut, dimana faktor penguasa serta sistem pemerintahan memberikan pengaruh yang besar. Berdasarkan uraian diatas maka dapat dirumuskan permasalahan sebagai berikut: (1) Bagaimanakah pengaturan prinsip netralitas ASN di negara Indonesia?, dan (2) bagaimanakah implementasi prinsip netralitas ASN di negara Indonesia?

\section{PEMBAHASAN}

\section{A. Prinsip Netralitas Aparatur Sipil Negara}

Netralitas ASN adalah persoalan yang sangat besar dalam kehidupan berbangsa dan bernegara, karena secara teoritis sulit ditemukan landasan teoritis yang dapat memberikan alasan pembenar bagi dimungkinkannya pegawai negeri untuk terlibat dalam kegiatan-kegiatan politik praktis (Mahfud, 1999:69). Senada dengan pendapat Mahfud, Thoha (2008:8) menyebutkan bahwa netralitas Pegawai Negeri Sipil (PNS) terhadap pengaruh dan intervensi politik tidak bisa dianggap ringan, PNS seyogianya tidak memihak atau sengaja dibuat memihak kepada salah satu kekuatan politik atau partai politik. Apabila PNS netral, maka rakyat secara keseluruhan akan bisa dilayani dengan baik dengan kata lain tidak mengutamakan atau memihak pada salah salah satu kepentingan kelompok rakyat tertentu. Oleh sebab itu, dalam upaya menjaga netralitas PNS dari pengaruh partai politik dan untuk menjamin keutuhan, kekompakan, dan persatuan PNS, serta dapat memusatkan segala perhatian, pikiran, dan tenaga pada tugas yang dibebankan, PNS dilarang menjadi anggota dan/atau pengurus partai politik.

Marbun (1998: 74) menyebutkan bahwa yang dimaksud dengan netralitas adalah: (1) bebasnya PNS dari pengaruh kepentingan partai politik tertentu atau tidak memihak untuk kepentingan partai tertentu atau tidak berperan dalam proses politik. Namun, PNS masih mempunyai hak politik untuk memilih dan berhak untuk dipilih dalam pemilihan umum, namun tidak diperkenankan aktif menjadi anggota dan pengurus partai politik. (2) PNS yang aktif menjadi pengurus partai politik atau anggota legislatif, maka harus 
mengundurkan diri, dengan demikian birokrasi akan stabil dan dapat berperan dalam mendukung serta merealisasikan kebijakan atas kehendak politik maupun yang sedang berkuasa dalam pemerintahan.

Secara normatif, menurut Undang-undang No. 5 tahun 2014 tentang Aparatur Sipil Negara, netralitas diartikan bebas dari pengaruh dan intervensi semua golongan dan partai politik. Dalam upaya menjaga netralitas ASN dari pengaruh partai politik dan untuk menjamin keutuhan, kekompakan, dan persatuan ASN, serta dapat memusatkan segala perhatian, pikiran, dan tenaga pada tugas yang dibebankan, maka ASN dilarang menjadi anggota dan/ atau pengurus partai politik.

Dengan demikian makna netralitas adalah bebasnya PNS dari pengaruh kepentingan partai politik tertentu dan tidak memihak untuk kepentingan partai tertentu atau tidak memihak untuk kepentingan partai tertentu atau tidak berperan dalam proses politik karena dikhawatirkan pegawai tersebut menyalahgunakan penggunaan fasilitas negara untuk kepentingan partai politik (Hartini, dkk, 2014: 80).

\section{B. Pengaturan Netralitas Aparatur Sipil}

\section{Negara}

Dalam sejarahnya, pengaturan netralitas Pegawai Negeri Sipil dapat dilihat dari masa Orde Lama, Orde Baru, Orde Reformasi dan pasca Orde Reformasi. Pada masa Orde Lama ditandai dengan diberlakukannya Undang-undang Darurat No. 25 tahun 1950 tentang Hak Mengangkat Pegawai Negeri Sipil, selanjutnya diterbitkan Undang-undang No.20 tahun 1952 tentang Pensiun Pegawai Negeri Sipil dan Undangundang No.21 tahun 1952 yang menyempurnakan Undangundang Darurat No.25 tahun 1950 tentang Hak Mengangkat Pegawai Negeri Sipil (Abdullah, 1986: 6).

Sampai dengan tahun 1960, pemerintah lebih banyak menerbitkan aturan-aturan kepegawaian dalam bentuk peraturan pemerintah. Hal ini mengakibatkan aparat pemerintah mengalami kesulitan untuk mendapatkan landasan hukum dalam menyelesaikan permasalahan kepegawaian dengan tepat. Oleh sebab itu, pemerintah berinisiatif menyusun undang undang kepegawaian yang bersifat menyeluruh. Pada tahun 1958, pemerintah membentuk panitia yang diketuai Prajudi Atmosoedirjo untuk menyusun undang undang kepegawaian. Pada tahun 1961, melalui proses politik berhasil diundangkan Undangundang No.18 tahun 1961 tentang Ketentuan Pokok Kepegawaian (Satoto, 2004: 31).

Undang-undang No.18 tahun 1961 ini sama sekali tidak mengatur tentang netralitas PNS. Namun demikian, secara de facto PNS terkotak-kotak dalam partai politik sebagai akibat situasi politik dan pemerintahan pada saat itu. Pada saat itu partai-partai politik mulai menanamkan pengaruhnya terhadap aparat pemerintah dan menggunakan pejabat pemerintah sebagai building block organisasi mereka. Partaipartai politik mempunyai masa pengaruh dan masa pendukung di setiap departemen, atau bahkan mendominasi departemen. Dengan demikian intervensi politik dalam kehidupan birokrasi sangat besar sekali. Maklumat Wakil Presiden tanggal 3 Nopember 1945 telah menimbulkan sistem multi partai yang memberikan kebebasan kepada masyarakat untuk mendirikan partai politik sesuai dengan aspirasinya. Pada masa itu dilaksanakan Pemilihan Umum yang pertama. Dari hasil pemilihan umum tersebut, partaipartai politik yang memenangkan suara berkehendak untuk menguasai beberapa kementerian. Bahkan tidakjarang terjadi kabinet pemerintahan dibubarkan hanya karena pembagian kementerian yang tidak sesuai dengan tuntutan partai-partai politik. Pemerintah dibawah kepemimpinan partai politik yang anggotanya mendominasi Dewan Perwakilan Rakyat. Kedudukan Dewan Perwakilan Rakyat sangat kuat. Sebaliknya lembaga-lembaga pemerintah kedudukannya sangat lemah. Pegawai Negeri Sipil yang seharusnya loyal kepada negara dan bangsa Indonesia akan tetapi dalam kenyataannya menjadi loyalis partai-partai politik. (Thoha, 2010: 115-132).

Permendagri No. 12 tahun 1968 yang antara lain berisi kewajiban aparat pemerintah untuk loyal kepada bangsa dan negara dan dilarang menjadi anggota partai politik. Kemudian berdasarkan Peraturan Pemerintah No.6 tahun 1970, mengharuskan setiap Pegawai Negeri untuk masuk dalam Korp Karyawan Departemen Dalam Negeri (Kokarmendagri), selanjutnya pada tahun 1971 berdasarkan Keputusan Presiden No.82 tahun 1971, dibentuklah Korps Pegawai Republik Indonesia (KORPRI) sebagai satu-satunya wadah pembinaan bagi PNS di luar kedinasan. Walaupun dalam perkembangannya dikemudian hari KORPRI mnejadi 


\section{MEDIA
HUKUM}

kendaraan politik dan secara transparan berafiliasi kepada keuatan politik tertentu.

Setelah Orde Lama runtuh maka mulailah Indonesia dibawah kekuasaan rezim Orde Baru. Pada masa Orde Baru, diterbitkanlah Undang-undang No.8 tahun 1974 tentang Pokok Pokok Kepegawaian yang menggantikan Undangundang No.18 tahun 1961.

Dalam Pasal 14 Undang-undang No.8 tahun 1974, disebutkan:

Untuk lebih meningkatkan pembinaan, keutuhan, dan kekompakan serta dalam rangka usaha menjamin kesetiaan dan ketaatan penuh seluruh Pegawai Negeri Sipil terhadap Pancasila, Undang-Undang Dasar 1945, Negara, dan Pemerintah, perlu dipupuk dan dikembangkan jiwa korps yang bulat di dan Pemerintah, perlu dipupuk dan dikembangkan jiwa korps yang bulat dan kalangan Pegawai Negeri Sipil. Untuk lebih meningkatkan pembinaan, keutuhan, dan kekompakan serta dalam rangka usaha menjamin kesetiaan dan ketaatan penuh seluruh Pegawai Negeri Sipil terhadap Pancasila, Undang-Undang Dasar 1945, Negara, dan Pemerintah, perlu dipupuk dan dikembangkan jiwa korps yang bulat di dan Pemerintah, perlu dipupuk dan dikembangkan jiwa korps yang bulat dan kalangan Pegawai Negeri Sipil.

Pengaturan dalam pasal diatas adalah sebagai akibat dari terkotak-kotaknya ASN pada masa Orde Lama. Oleh sebab itu, pemerintah Orde Baru menginginkan adanya persatuan dan kesatuan ASN dengan cara mengembangkan jiwa korsa ASN. Pada masa berlakunya Undang-undang No.43 tahun 1999, pengaturan netralitas lebih jelas dan tegas. Hal ini dapat dilihat pada Pasal 3 ayat (2), yang menyebutkan:

Dalam kedudukan dan tugas sebagaimana dimaksud dalam ayat (1), Pegawai negeri harus netral dari pengaruh semua golongan dan partai serta tidak diskriminatif dalam memberikan pelayanan kepada masyarakat.

Sebagai pelaksanaan Undang-undang No.43 Tahun 1999, diterbitkan Peraturan Pemerintah No.5 Tahun 1999 tentang Pegawai Negeri Sipil yang menjadi Anggota Partai Politik. Adapun pengaturan tentang netralitas Pegawai Negeri Sipil tersurat dalam Pasal 3 sampai dengan Pasal 9, ketentuan tersebut adalah:

1. Dalam kedudukan sebagaimana aparatur negara, abdi negara dan abdi masyarakat, Pegawai Negeri Sipil harus bersikap netral dan menghindari penggunaan fasilitas negara untuk golongan tertentu;

2. a. Pegawai Negeri Sipil yang telah menjadi anggota dan atau pengurus partai politik pada saat Peraturan Pemerintah ini ditetapkan dianggap telah melepaskan keanggotaan dan atau kepengurusannya.

b. Pegawai Negeri Sipil, apabila tetap menjadi anggota dan atau pengurus partai politik, selambat-lambatnya dalam waktu 3 (tiga) bulan setelah berlakunya Peraturan Pemerintah ini harus melaporkan kepada pejabat yang berwenang.

c. Bagi Pegawai Negeri Sipil yang melaporkan keanggotaan dan atau kepengurusannya dalam tenggang waktu 3 (tiga) bulan diberhentikan dari jabatan negeri dan diberikan uang tunggu sebesar gaji pokok terakhir.

d. Bagi Pegawai Negeri Sipil yang tetap menjadi anggota dan atau pengurus partai politik, apabila dalam tenggang waktu 3 (tiga) bulan tidak melaporkan kepada pejabatyang berwenang maka diebrehentikan tidak dengan hormat sebagai Pegawai Negeri.

3. a. Pegawai Negeri Sipil yang menjadi anggota dan atau pengurus partai politik diberhentikan dari jabatan negeri dan diberikan uang tunggu sebesar gaji pokok terakhir. b. Pegawai Negeri Sipil, wajib melaporkan keanggotaan dan kepengurusannya dalam partai politik kepada pejabat yang berwenang dalam jangka waktu selambat-lambatnya 3 (tiga) bulan sejak yang bersangkutan secara resmi menjadi anggota dan atau pengurus partai politik.

c. Pegawai Negeri Sipil yang tidak melaporkan keanggotaan dan atas kepengurusannya dalam partai politik, diberhentikan tidak dengan hormat sebagai Pegawai Negeri Sipil.

4. Pegawai Negeri Sipil yang telah diberhentikan dari jabatan negeri karena keanggotaan dan atau kepengurusannya dalam partai politik, dapat diaktifkan kembali dalam jabatan negeri, apabila ia melepaskan keanggotaan dan atau kepengurusannya. 
Pengaktifan kembali hanya dapat dilakukan dalam jangka waktu 1 (satu) tahun sejak yang bersangkutan secara resmi menjadi anggota dan atau pengurus partai politik.

Selanjutnya diterbitkan Peraturan Pemerintah No.12 Tahun 1999 yang merubah beberapa pasal dalam Peraturan Pemerintah No.5 tahun 1999 khususnya Pasal 7, 8 dan 9. Adapun ketentuan pasal-pasal tersebut adalah:

Pasal 7

(1) Pegawai Negeri Sipil yang telah menjadi anggota dan atas pengurus partai politik pada saat Peraturan Pemerintah ini ditetapkan, maka keanggotaan dan atau kepengurusan yang bersangkutan hapus secara otomatis.

(2) Pegawai Negeri Sipil sebagaimana dimaksud dalam ayat (1) apabila tetap menjadi anggota dan atau pengurus partai politik, selambat-lambatnya dalam waktu 3 (tiga) bulan setelah berlakunya Peraturan Pemerintah ini harus mengajukan permohonan melalui atasan langsung dan apabila diizinkan maka yang bersangkutan melepaskan jabatan negeri.

(3) Bagi Pegawai Negeri Sipil sebagaimana dimaksud dalam ayat (2) yang melepaskan jabatan negeri berlaku ketentuan Pasal 8.

(4) Bagi Pegawai Negeri Sipil sebagaimana dimaksud dalam ayat (1) yang tetap menjadi anggota dan atau pengurus partai politik, apabila dalam tenggang waktu sebagaimana tersebut dalam ayat (2) tidak mengajukan permohonan melalui atasan langsung diberhentikan tidak dengan hormat.

Pasal 8

Pegawai Negeri Sipil yang menjadi anggota dan atau pengurus partai politik diberhentikan dari jabatan negeri dan diberikan uang tunggu sebesar gaji pokok terakhir selama satu tahun.

Pasal 9

(1) Pegawai Negeri Sipil yang telah diberhentikan dari jabatan negeri karena keanggotaan dan atau kepengurusannya dalam partai politik, dapat diaktifkan kembali dalam jabatan negeri apabila ia melepaskan keanggotaan dan atau kepengurusannya.

(2) Pengaktifan kembali sebagaimana dimaksud dalam ayat (1) hanya dapat dilakukan sebelum jangka waktu 1 (satu) tahun sebagaimana ditentukan dalam Pasal 8 berakhir.
Pemerintah juga menerbitkan Peraturan Pemerintah No.53 Tahun 2010 tentang Disiplin Pegawai Negeri Sipil juga mengatur tentang netralitas Pegawai Negeri Sipil. Hal ini dapat dilihat dalam Pasal 4 yang menyebutkan bahwa Pegawai Negeri Sipil dilarang: memberikan dukungan kepada calon Presiden/Wakil Presiden, Dewan Perwakilan Rakyat, Dewan Perwakilan Daerah, atau Dewan Perwakilan Rakyat Daerah dengan cara: a. ikut serta sebagai pelaksana kampanye; b. menjadi peserta kampanye dengan menggunakan atribut partai atau atribut Pegawai Negeri Sipil; c. sebagai peserta kampanye dengan mengerahkan Pegawai Negeri Sipil lain; dan/atau d. sebagai peserta kampanye dengan menggunakan fasilitas negara;

Pegawai Negeri Sipil juga dilarang memberikan dukungan kepada calon Presiden/ Wakil Presiden dengan cara:

a. membuat keputusan dan/atau tindakan yang menguntungkan atau merugikan salah satu pasangan calon selama masa kampanye; dan/atau

b. mengadakan kegiatan yang mengarah kepada keberpihakan terhadap pasangan calon yang menjadi peserta pemilu sebelum, selama, dan sesudah masa kampanye meliputi pertemuan, ajakan, himbauan, seruan, atau pemberian barang kepada PNS dalam lingkungan unit kerjanya, anggota keluarga, dan masyarakat;

Selain itu Pegawai Negeri Sipil juga dilarang memberikan dukungan kepada calon anggota Dewan Perwakilan Daerah atau calon Kepala Daerah/Wakil Kepala Daerah dengan cara memberikan surat dukungan disertai foto kopi Kartu Tanda Penduduk atau Surat Keterangan Tanda Penduduk sesuai peraturan perundang-undangan; dan memberikan dukungan kepada calon Kepala Daerah/Wakil Kepala Daerah, dengan cara:

a. terlibat dalam kegiatan kampanye untuk mendukung calon Kepala Daerah/ Wakil Kepala Daerah;

b. menggunakan fasilitas yang terkait dengan jabatan dalam kegiatan kampanye;

c. membuat keputusan dan/atau tindakan yang menguntungkan atau merugikan salah satu pasangan calon selama masa kampanye; dan/atau

d. mengadakan kegiatan yang mengarah kepada keberpihakan terhadap pasangan calon yang menjadi peserta pemilu sebelum, selama, dan sesudah masa kampanye 


\section{MEDIA
HUKUM}

meliputi pertemuan, ajakan, himbauan, seruan, atau pemberian barang kepada PNS dalam lingkungan unit kerjanya, anggota keluarga, dan masyarakat.

Pengaturan selanjutnya Kepala Badan Kepegawaian Negara menerbitkan Surat Kepala Badan Kerpegawaian Negara No.K.26-17/N.19-14/99 perihal PNS yang menjadi anggota partai politik, menyebutkan bahwa PNS harus netral dari pengaruh semua golongan dan partai politik serta tidak diskriminatif dalam memberikan pelayanan kepada masyarakat. Untuk menjamin netralitas PNS, maka dilarang menjadi anggota dan atau pengurus partai politik. Dalam upaya menjaga netralitas PNS dari pengaruh partai politik dan untuk menjamin keutuhan, kekompakan, dan persatuan pegawai Negeri, serta agar dapat memusatkan segala perhatian, pikiran, dan tenaganya pada tugas yang dibebankan kepadanya, maka PNS dilarang menjadi anggota dan atau pengurus partai politik. Oleh karena itu, Pegawai Negeri yang menjadi anggota dan atau pengurus partai politik harus diberhentikan sebagai PNS. Pemberhentian tersebut dapat dilakukan dengan hormat atau tidak dengan hormat.

Berkaitan dengan sanksi bagi PNS yang tidak netral maka menteri Pendayagunaan Aparatur Negara menerbitkan Surat Edaran Menteri Pendayagunaan Aparatur Negara No.SE/ 18.1/M.PAN/5/2004. Surat edaran ini mengatur tentang kriteria penjatuhan sanksi bagi Pegawai Negeri Sipil yang tidak netral. Kriteria tersebut adalah:

a. Hukuman disiplin tingkat berat berupa penurunan pangkat setingkat lebih rendah untuk paling lama 1 (satu) tahun bagi PNS yang terlibat dalam kampanye pemilihan umum Presiden dan Wakil Presiden atau mengizinkan penggunaan fasilitas pemerintah karena jabatannya.

b. Hukuman disiplin tingkat berat berupa pembehentian dengan hormat tidak atas permintaan sendiri sebagai Pegawai Negeri Sipil dengan hak-hak kepegawaian sesuai peraturan perundang-undangan yang berlaku, bagi Pegawai Negeri Sipil yang terlibat dalam kampanye dan berkedudukan sebagai Tim sukses atau yang sejenis dalam pemilihan umum Presiden dan wakil Presiden.

c. Hukuman disiplin tingkat berat berupa pemberhentian tidak dengan hormat sebagai Pegawai Negeri Sipil, bagi Pegawai Negeri Sipil yang terlibat dalam kampanye Pemilu Presiden dan Wakil Presiden berkedudukan sebagai anggota atau pengurus Partai Politik atau Tim sukses atau sejenis dalam Pemilu Presiden dan Wakil Presiden serta menggunakan fasilitas oleh karena jabatannya.

Pada tahun 2014, diterbitkan Undang-undang No.5 tahun 2014 tentang Aparatur Sipil Negara untuk menggantikan Undang-undang No.43 tahun 1999. Dalam Pasal 12 disebutkan bahwa ASN berperan sebagai perencana, pelaksana, dan pengawas penyelenggaraan tugas umum pemerintahan dan pembangunan nasional melalui pelaksanaan kebijakan dan pelayanan publik yang profesional, bebas dari intervensi politik, serta bersih dari praktik korupsi, kolusi, dan nepotisme. Dalam undang undang ini juga mengatur tentang pembentukan Komisi Aparatur Sipil Negara (KASN) yang mandiri dan bebas dari intervensi politik. Pembentukan KASN ini untuk monitoring dan evaluasi pelaksanaan kebijakan dan Manajemen ASN untuk menjamin perwujudan Sistem Merit serta pengawasan terhadap penerapan asas, kode etik dan kode perilaku ASN. Selain itu sesuai dengan Pasal 54, Undang undang ini mendelegasikan kewenangan pembinaan Manajemen ASN kepada Pejabat yang Berwenang di kementerian, sekretaris jenderal/ sekretariat lembaga negara, sekretariat lembaga nonstruktural, sekretaris daerah provinsi dan kabupaten/kota.

Pejabat yang berwenang dalam menjalankan fungsi Manajemen ASN di Instansi Pemerintah berdasarkan Sistem Merit dan berkonsultasi dengan Pejabat Pembina Kepegawaian di instansi masing-masing. Selanjutnya Pejabat yang Berwenang, memberikan rekomendasi usulan kepada Pejabat Pembina Kepegawaian di instansi masing-masing. Pejabat yang Berwenang mengusulkan pengangkatan, pemindahan, dan pemberhentian Pejabat Administrasi dan Pejabat Fungsional kepada Pejabat Pembina Kepegawaian di instansi masing-masing. Pengaturan ini diupayakan untuk meminimalisasi dan menghilangkan sama sekali intervensi partai politik melalui pejabat pembina kepegawaian kepada Pegawai Negeri Sipil sebagaimana telah terjadi pada masa berlakunya Undang-undang No. 43 tahun 1999. 


\section{Implementasi Netralitas Aparatur Sipil}

\section{Negara}

Pada masa Orde Baru, sistem pemerintahan Indonesia tersentralisasi pada pemerintah pusat. Demikian pula halnya dengan pembinaan kepegawaian dilakukan secara sentral oleh pemerintah pusat. Daerah tidak mempunyai wewenang dalam pembinaan kepegawaian baik dalam hal penetapan pengangkatan, pemindahan maupun pemberhentian PNS.

Pada saat itu akibat pengaruh politik, PNS wajib loyal pada Golongan Karya atau monoloyalitas. PNS wajib mendukung dan memilih Golongan Karya dalam setiap Pemilihan Umum. Pada masa itu, slogan kebijakan pemerintah menjadikan birokrasi pemerintah netral dari partai politik. PNS dilarang memasuki partai politik, akan tetapi kebijakan ini merupakan siasat politik belaka. Pemerintah memaksa PNS untuk menjadi anggota Golkar yang bukan partai politik akan tetapi bergerak di area politik praktis. PNS dilarang masuk dalam partai politik yang pada waktu itu hanya ada dua yaitu Partai Persatuan Pembangunan (PPP) dan Partai Demokrasi Indonesia (PDI), namun diperbolehkan memasuki Golkar. Inilah pengaturan dan kebijakan netralitas PNSI pada masa Orde Baru. Pada masa itu, sangat sulit membedakan mana pejabat karir dan mana pejabat yang merupakan partisan kekuatan politik Golkar. Pemerintahan Orde Baru menggunakan sistem karir dalam peraturan kepegawaiannya namun hampir semua pejabat pemerintah merupakan partisan dari kekuatan politik yang memerintah sebagai mayoritas tunggal. Setiap pengangkatan seseorang pada jabatan pemerintahan, pertimbangan yang digunakan adalah keanggotaan dan dukungan kekuatan Golkar. Tentu saja hal ini merupakan bentuk intervensi kekuatan politik Golkar yang dapat menganggu kenetralan birokrasi pemerintahan. Pergantian jabatan sekjen, Dirjen dan Irjen oleh Menteri baru karena pejabat-pejabat lama tidak sealiran politik dengan Menteri merupakan contoh dari inbtervensi politik ke birokrasi pemerintah (Thoha, 2008:9).

Pada masa itu sudah ada beberapa peraturan perundangundangan yang mengatur netralitas birokrasi, misalnya Peraturan Pemerintah No. 5 Tahun 1999 tentang Pegawai Negeri Sipil Yang Menjadi Anggota Partai Politik dan Peraturan Pemerintah No.12 tahun 1999 tentang Perubahan atas Peraturan Pemerintah No.5 Tahun 1999. Peraturan pemerintah ini mewajibkan PNS untuk netral dan menghindari penggunaan fasilitas untuk kepentingan golongan tertentu. Bagi PNS yang menjadi anggota atau pengurus partai politik wajib mengundurkan diri dari kedudukannya sebagai PNS.

Reformasi yang terjadi pada bulan Mei 1998 telah mengakibatkan perubahan yang signifikan dalam tata kehidupan sistem politik dan sistem pemerintahan negara. Salah satu perubahan tersebut adalah munculnya desentralisasi kepada daerah untuk mengelola sendiri segala urusannya diluar urusan agama, pertahanan keamanan, keuangan, politik. Hal ini ditandai dengan diterbitkannya Undang-undang No. 22 Tahun 1999 tentang Pemerintah Daerah. Kewenangan daerah tersebut antara lain adalah kewenangan dalam bidang kepegawaian. Hal-hal tersebut yang kemudian menjadi pertimbangan perubahan atas Undang-undang No.8 tahun 1974. Pemerintah merasa bahwa perubahan sistem politik dan sistem pemerintahan belum terwadahi dalam aturan hukum yang sudah ada, sehingga pada tahun 1999 diterbitkan Undang-undang No.43 tahun 1999 (Effendi, 1999: 1).

Pasal 3 ayat (2) Undang-undang No.43 tahun 1999 menyebutkan "Dalam kedudukan dan tugas sebagai unsur aparatur negara yang memberikan pelayanan kepada masyarakat maka PNS harus netral dari semua pengaruh golongan dan partai politik serta tidak diskriminatif dalam memberikan pelayanan kepada masyarakat. Selanjutnya dalam ayat (3) disebutkan bahwa untuk menjamin netralitas PNS maka setiap PNS dilarang menjadi anggota dan atau pengurus partai politik.

Berdasarkan ketentuan tersebut di atas maka menurut undang undang ini, netralitas PNS diartikan dengan tidak menjadi anggota dan atau pengurus partai politik. Selanjutnya dalam Peraturan Pemerintah No.9 tahun 2003 tentang Wewenang Pengangkatan, Pemindahan dan Pemberhentian Pegawai Negeri Sipil menyebutkan bahwa ada tiga pejabat pembina kepegawaian yaitu:

1. Pejabat Pembina Kepegawaian Tingkat Pusat (Presiden)

2. Pejabat Pembina Kepegawaian Tingkat Propinsi (Gubernur)

3. Pejabat Pembina Kepegawaian Tingkat Kabupaten/Kota (Bupati/Walikota) 


\section{MEDIA
HUKUM}

Pejabat pembina kepegawaian tersebut mempunyai kewenangan untuk mengangkat, memindahkan dan memberhentikan PNS di lingkungannya. Kewenangan ini sering kali disalahgunakan oleh pejabat pembina kepegawaian terhadap para PNS di lingkungannya yang mempunyai pandangan politik berbeda. Pejabat pembina kepegawaian yang berasal dari partai politik sering melakukan intervensi politik kepada pada PNS di lingkungannya agar supaya mempunyai pandangan politik yang sama. Inilah problematika pembinaan kepegawaian ketika pejabat pembina kepegawaian yang seharusnya berlaku profesional, adil serta obyektif dalam pelaksanaan pembinaan kepegawaian tetapi menyalahgunakan kewenangannya. Hal ini terjadi akibat kedudukan kepala daerah yang disatu sisi merupakan pejabat politik atau representasi dari partai politik dan disisi lain merupakan pejabat pembina kepegawaian yang harus senantiasa obyektif.

Fenomena ini merupakan fakta empiris atas pendapat Carino, bahwa pejabat politik telah mendominasi birokrasi. Pejabat politik dengan kewenangannya telah memaksa para PNS untuk mengikuti kehendak politiknya. Pola hubungan ini dikenal dengan excecutive ascedency dimana birokrasi sebagai sub ordinasi dari politik (Thoha, 2010: 153).

\section{SIMPULAN}

Berdasarkan uraian diatas maka dapat disimpulkan sebagai berikut:

1. Aturan netralitas Aparatur Sipil Negara baru dimulai pada masa Orde Baru, yaitu ketika berlakunya Undang-undang No.43 Tahun 1999 tentang Pokok Pokok Kepegawaian, pengaturan netralitas ASN pada kesatuan korps mengingat pada masa Orde Lama, ASN terkota-kotak dan terpecah belah dalam afiliasi partai politik yang berbedabeda. Sementara pengaturan lebih tegas dapat dilihat pada Peraturan Pemerintah No. 5 Tahun 1999 dan Peraturan Pemerintah No. 12 tahun 1999, Peraturan Pemerintah No.53 tahun 2010 tentang Disiplin Pegawai Negeri Sipil dan Surat Kepala Badan Kepegawaian Negara No.K.26-17/N.19-14/99 perihal PNS yang menjadi anggota partai politik Surat Kepala Badan Kepegawaian Negara No.K.26-17N.19-14/99 perihal PNS yang menjadi anggota partai politik serta Surat Edaran Menteri
Pendayagunaan Aparatur Negara No.SE/18.1/M.PAN/5/ 2004. Surat edaran ini mengatur tentang kriteria penjatuhan sanksi bagi PNS yang tidak netral.

2. Sepanjang masa, dari mulai masa Orde Lama sampai dengan sekarang, ASN senantiasa menjadi alat bagi partai politik. Sehingga prinsip netralitas ASN sulit diwujudkan, ASN menjadi sub ordinasi partai politik. Barulah pada masa pasca Orde Reformasi saat ini, diterbitkan Undangundang No.5 Tahun 2014 yang berupaya menyelesaikan persoalan netralitas ASN ini dengan membentuk Komisi Aparatur Sipil Negara untuk mengawasi pelaksanaan prinsip netralitas ASN dalam praktek kepegawaian di negara kita.

\section{DAFTAR PUSTAKA}

Abdulah, Rozali, 1986, Hukum Kepegawaian di Indonesia, Jakarta, Rajawali Press

Hartini, Sri, dkk, 2014, Hukum Kepegawaian di Indonesia, Jakarta, Sinar Grafika

Kurniawan, Agung, 2005, Transformasi Pelayanan Publik, Yogyakarta: Pembaruan

Lailam, Tanto, 2017, Teori dan Hukum Perundangundangan, Yogyakarta, Pustaka Pelajar

Mahfud, Mohd, 1998, Politik Hukum di Indonesia, LP3ES, Jakarta

_, 1999, Pergulatan Politik dan Hukum di Indoensia, Gama Media, Yogyakarta

Marbun, 1998, Reformasi Hukum Tata Negara, Netralitas Pegawai Negeri dalam Kehidupan Politik di Indonesia, Fakultas Hukum Universitas Islam Indonesia, Yogyakarta

Satoto, Sukamto, 2004, Pengaturan Eksistensi dan Fungsi Badan Kepegawaian Negara, Yogyakarta: CV Hanggar Kreator

Sirajudin, Didik Sukriono dan Winardi, 2011, Hukum Pelayanan Publik Berbasis Partisipasi dan keterbukaan Informasi, Setara Press

Spicker, Paul, 1988, Principles of Social Welfare-An Introduction to Thinking About The Welfare state, Routledge, London

Thoha, Miftah,2008, Menejemen Kepegawaian Sipil di Indonesia, Kencana Prenada Media Group, Jakarta

, 2010, Birokrasi dan Politik di Indonesia, Rajawali Press, Jakarta 
Utomo, Warsito, 2006, Administrasi Publik Baru Indonesia: Perubahan Paradigma dari Administrasi Negara ke Administrasi Publik, Pustaka Pelajar, Yogyakarta

\section{Artikel, Karya Ilmiah}

Effendi, Sofian, 1999, Kebijakan kepegawaian Negara dalam rangka Penyelenggaraan Pemerintahan pasca Pemilu 1999, makalah, tidak diterbitkan

_, 2000 , re-Reformasi Kepegawaian, makalah, tidak diterbitkan

___-, 2013, Godot dan Reformasi Birokrasi, Harian Kompas edisi Senin 13 Mei 2013, opini

\section{Peraturan Perundang-undangan}

Undang Undang Darurat Nomor 25 tahun 1950 tentang Hak Mengangkat Pegawai Negeri Sipil

Undang Undang Nomor 20 tahun 1952 tentang Pensiun Pegawai Negeri Sipil

Undang Undang Nomor 21 tahun 1952 tentang perubahan atas Undang Undang Darurat Nomor 25 tahun 1950 tentang Hak Mengangkat Pegawai Negeri Sipil

Undang Undang Nomor 18 tahun 1961 tentang Pokok Pokok Kepegawaian

Undang Undang Nomor 8 tahun 1974 tentang Pokok Pokok Kepegawaian

Undang Undang Nomor 43 tahun 1999 tentang Perubahan atas Undang Undang Nomor 8 tahun 1974 tentang Pokok Pokok Kepegawaian

Undang Undang Nomor 5 tahun 2014 tentang Aparatur Sipil Negara

Peraturan Pemerintah Nomor 5 tahun 1999 tentang Pegawai Negeri Sipil yang menjadi Anggota Partai Politik

Peraturan Pemerintah Nomor 12 tahun 1999 tentang Perubahan atas Peraturan Pemerintah Nomor 5 tahun 1999 tentang Pegawai Negeri Sipil yang menjadi Anggota Partai Politik

Peraturan Pemerintah Nomor 53 tahun 2010 tentang Disiplin Pegawai Negeri Sipil

Kepala Badan Kerpegawaian Negara Nomor K.26-17/ V.19-14/99 perihal Pegawai Negeri Sipil yang menjadi anggota partai politik Surat Kepala Badan Kerpegawaian Negara Nomor K.26-17/V.19-14/99 perihal Pegawai Negeri Sipil yang menjadi anggota partai politik

Surat Edaran Menteri Pendayagunaan Aparatur Negara No.SE/18.1/M.PAN/5/2004. Surat edaran ini mengatur tentang kriteria penjatuhan sanksi bagi Pegawai Negeri Sipil yang tidak netral 